\title{
The structural control of the Mroczna Cave development on the slopes of Mt Kornuty (the Flysch Carpathians, Beskid Niski Mts)
}

\author{
Michał Zatorski \\ Institute of Geography and Spatial Management, Jagiellonian University, Kraków, Poland, e-mail: michal.zatorski@uj.edu.pl
}

\begin{abstract}
The Mroczna Cave is one of the longest caves in the Beskid Niski Mts., located on the south-western slopes of Mt Kornuty, along the main scarp of the landslide. According to the geomechanical criterion, it is dilation cave, where extension has played a major role. Morphotectonic analysis indicates that the main gravitational movement was of a toppling nature but there were also rotation around the vertical axis as well as a backward rotation. The relatively large cave depth $(15.5 \mathrm{~m})$ and its shape (cross-section of its passages) indicate that it was formed along a new gravitational cutting surface of the rock massif, associated with joint sets.
\end{abstract}

Key words: mass movements, the Flysch Carpathians, crevice-type cave, structural control, anisotropic rock massif

\section{Introduction}

In the course of regularly held International Pseudokarst Symposia, representatives from different fields of science and speleologists involved in the exploration of caves have quite precisely described the concept of pseudokarst. It was established that pseudokarst forms are morphologically similar to karst (Urban, Mochoń 1991), but can form in both non-karst and karst rocks. Although the current opinion is that the term pseudokarst cannot be precisely defined, the term still holds significant scientific interest for researchers in specific fields (Urban 2014). This growing interest in pseudokarst forms has brought to light some fundamental research problems (Mochoń, Urban 1989, Klassek, Mikuszewski 1997). It has also opened up issues related to structural geomorphology. Of particular interest are the analyses that concern the determination of the mechanics and nature of gravitational movements, in the light of landslide development (Janiga 1974, Puchejda 1989, Margielewski 2002, Margielewski, Urban 2003, 2004).

The south-western slopes of Mt Kornuty in the Beskid Niski Mts. show distinctive landslide features. In relation to the spatial orientation of the bedding planes, the landslide represents the obsequent type, with the direction of mass movement opposite to the slope dip (Bober 1984). The high and almost vertical rocky head scarps indicate the structural control in the landslides of the Flysch Carpathians (Margielewski 1998, 2006). The action of tectonic processes have led to the formation of a joint network that is involved in the gravity driven movements. Rocks and deep-seated landslides are the result of a progressive development of extension-dilation crevices in anisotropic rock massifs. The location of a dilation cave within the zone of a main landslide scarp provides an opportunity to trace the slope relief evolution "from the inside." This also enables one to observe the crevice at the initial stage of increasing stresses and their relaxation, as well as in the phase of gravitational disintegration of the rock massif separated by the cave (Margielewski 1998, 2002, 2009, Margielewski, Urban 2003). The study of the spatial orientation of particular slope (massif) elements and their features within the Mroczna Cave allows one to determine the type of movements that led to the creation of this cave. Moreover, the variability of morphometric features illustrates the structural control of cave development. Finally, the study makes it possible to distinguish between the zones associated with secondary movements of rock blocks and those associated with the initial stage of the development of the landslide. 


\section{Geological structure and relief of the study area}

The Kornuty ridge, within which the Mroczna Cave is located, is composed of the so-called Wątkowa Sandstones, which represent a local facies variety of the Magura Formation (Oligocene) within the Magura (facies-tectonic) Unit (Fig. 1). This sandstone occurs in the core of the NW-SE elongation syncline that forms the Magura Wątkowska range with Mt Kornuty. High resistance of the Wątkowa Sandstone to erosion has contributed to the formation of rock outcrops along the ridge and in the upper part of the slope (Lach 1970, Alexandrowicz, Alexandrowicz 1988). The Wątkowa Sandstone has a siliceous-ferruginous cement without any carbonate admixture. High secondary porosity in the range of $4.07-10.04 \%$, associated with a system of joints, is involved in shaping the sandstone outcrops and the large natural rock forms in the Flysch Carpathians (Świdziński 1933, 1936, Tokarski 1946, Lach 1970, Alexandrowicz 1978).

The elevation of the Magura Watkowska range at $\mathrm{Mt}$ Kornuty is $829.5 \mathrm{~m}$ a.s.l. The ridge is flanked on both sides by steep slopes. At the height of $800 \mathrm{~m}$ a.s.l. the Watkowa Sandstones are outcropped, forming the main scarp of the landslide, which is up to $15 \mathrm{~m}$ high and 800 m long (Żytko 1973, Ślączka 1977, Alexandrowicz, Alexandrowicz 1988). Below the scarp, on the south-western slopes of Mt Kornuty, a vast landslide zone of the area of $1.48 \mathrm{~km}^{2}$ stretches out as far as the Bartnianka river (Fig. 2) (Świdziński 1936, Rączkowski et al. 1995, Kopciowski et al. 1997). It can be assumed that the entire area is part of a large multi-phase landslide composed of several types of gravitational mass movements (according to Margielewski 2009). This whole zone is divided by scarps laid out in tiers, separated by colluvial bodies and rock tongues. Rock boulders, of a length reaching up to $10 \mathrm{~m}$, predominate in the upper part of the landslide.
Some of them are toppled elements of the main scarp. An elongated depression (trench) about $800 \mathrm{~m}$ long, 3-5 m deep, up to $8 \mathrm{~m}$ wide, and parallel to the mains scarp is located between the scarp and the mountain ridge (Lach 1970). The depression has features of a ridge trench, similar to the ones described by Flis (1958) and Margielewski $(1992,1997,1999)$ in other parts of the Carpathians. In its south-eastern part, the trench was artificially deepened and strengthened for military purposes during World War I (the Gorlice Battle). The size of the rock boulders decreases downslope toward the lower part of the slope, forming colluvial swells and rock tongues. Currently, the movement of the colluvial material is usually limited to small rotational landslides at the toe of the colluvial tongues and solifluction at the bottom part of the slope. Thickly forested colluvial swells and tongues indicate that the whole landslide zone is currently at the stabilization stage (Jakubowski 1974). Large-scale landslide movements have not occurred there recently.

So far 13 pseudokarst caves have been recorded in the main scarp area and within the sandstone boulders below it (Pulina 1998, Gubała 2004, Kapturkiewicz 2006). Most of these caves are small and represent talus-type caves, i.e., cavities (empty spaces) between large rock blocks (Table 1) (Vitek 1983, Urban, Mochon 1991). With a length of $198 \mathrm{~m}$ and a depth of $15.5 \mathrm{~m}$, the Mroczna Cave is the longest and deepest among the caves of the Magura Watkowska range. The update by a recent inventory has not introduced any significant changes in the length and depth of this cave (Gubała 2004, Kapturkiewicz 2006). The system of passages in the Mroczna Cave is developed along the head scarp of the landslide, in a general NW-SE elongation. The shape and geomorphological location of the cave indicates that it is a crevice-type cave (developed owing to gravitational-dilational widening of joints). According to the morphogenetic classification of epigenetic pseudokarst caves, some passages represent

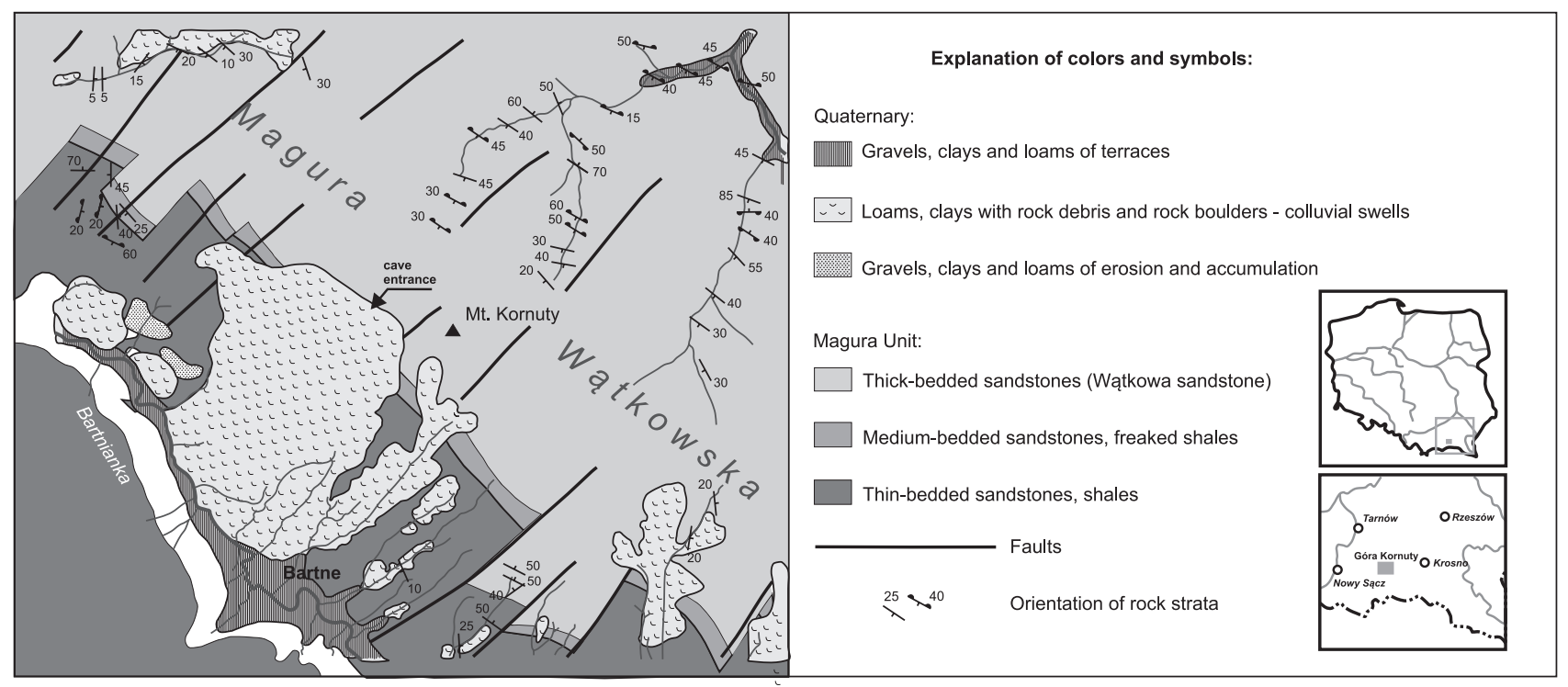

Fig. 1. Geological map of the south-western slopes of Mt Kornuty (after Kopciowski et al. 1997) 
fissure-type cave elements developed as the result of sandstone weathering along joints (Vitek 1983, Urban, Mochon 1991). According to the new morphogenetic categorization proposed by Urban and Margielewski (2013), the Mroczna Cave represents an intermediate type (between the initial and subsequent caves). Taking into account the geomechanical criterion of this classification, it is a dila- tion cave, where tension had an important role in its development. The spatial orientation of the Mroczna Cave passages and their shapes in cross-section represent the most suitable objects for morphotectonic analyses within the Magura Wątkowska range, allowing me to establish the types of gravitational mass movements that have occurred based on landslide development.

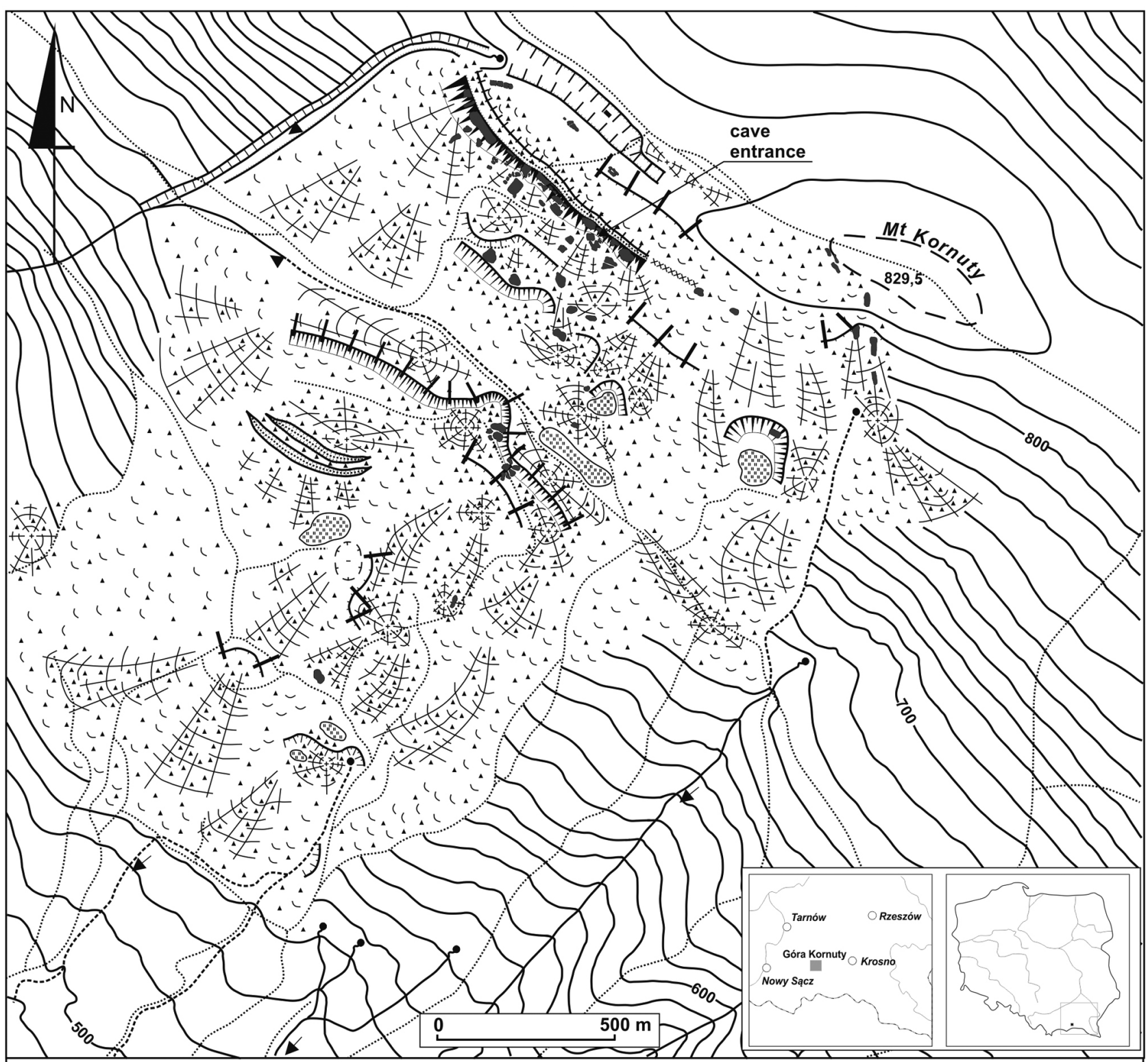

Explanation of symbols:

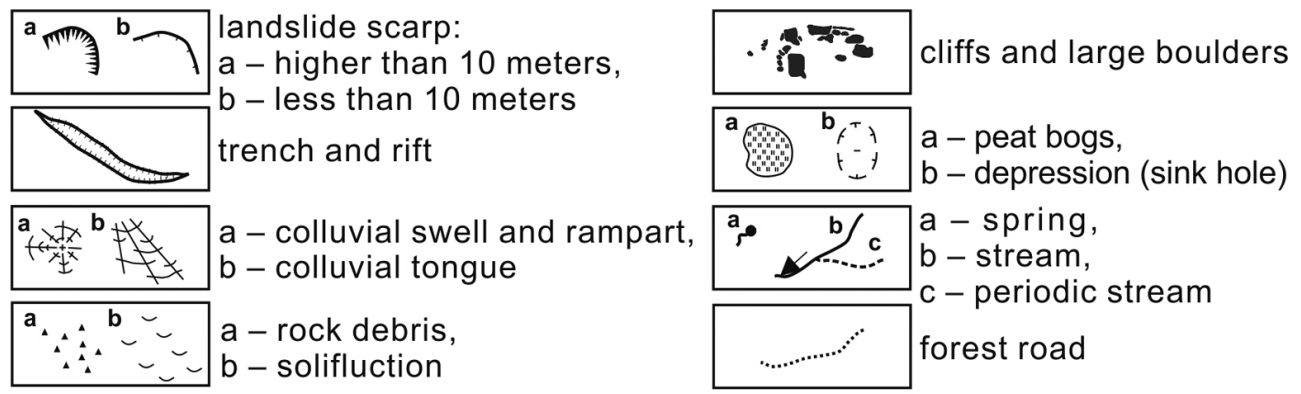

Fig. 2. Landslide zone on the south-western slopes of Mt Kornuty 
Table 1. List of caves on the south-western slopes of Mt Kornuty (after Gubała 2004)

\begin{tabular}{clcc}
\hline No. & Cave name & Length $(\mathrm{m})$ & Depth $(\mathrm{m})$ \\
\hline 1. & Mroczna Cave & 198 & 15.5 \\
2. & Kornuty I & 3.5 & less than 1 \\
3. & Kornuty II & 6 & less than 1 \\
4. & Kornuty III & 11 & about 2 \\
5. & Kornuty IV & 4 & less than 1 \\
6. & Kornuty V & 10 & less than 1 \\
7. & Kornuty VI & 5 & less than 1 \\
8. & Kornuty VII & 5 & less than 1 \\
9. & Kornuty VIII & 7 & less than 1 \\
10. & Kornuty IX & 5 & about 1 \\
11. & Kornuty X & 3 & 1.5 \\
12. & Kornuty XI & 7 & about 2 \\
13. & Kornuty XII & 3 & less than 1 \\
\hline
\end{tabular}

\section{Research methods}

During the field survey, 811 measurements of the spatial orientation of rock discontinuities were performed in the Mroczna Cave, separately for its upslope and downslope walls. The measurements were made using the Freiberg geological compass of $\pm 2^{\circ}$ accuracy. The results of the measurements are presented as contour diagrams (projections of poles on the lower hemisphere) and directional rose diagrams (with an accuracy of $10^{\circ}$, in the full range of the circle, from $0^{\circ}$ to $360^{\circ}$ ) for the upper side (upslope) and the lower side (downslope) walls of the cave, respectively. A comparison of the orientation of the upper side cave walls, which are partly elements of the main landslide scarp, with the orientation of the opposite (lower side) walls, which frame an "external" (downslope) rock massif, allows me to determine the types of mass movements within individual parts of the cave (Margielewski 2002, Margielewski, Urban 2003, 2004, Imrich et al. 2007, Margielewski et al. 2007). Contour diagrams and directional diagrams were supplemented by the strata (bedding planes) orientation and the classification of the joint sets, adopted from Mastella et al. (1997): L, L' - longitudinal, $\mathrm{D}_{1} \mathrm{D}_{2}$ - diagonal, $\mathrm{T}$ - transversal, with regard to the spatial orientation of the stratification. Using both diagrams (contour and directional), an attempt to determine the mechanics and the stages of gravitational movements in this part of the slope were made.

For the purpose of analysis and proper interpretation of these movements, the cave was divided into four morphologic parts. The number of measurements obtained was dependent on the availability of joints surfaces and their weathering. In the deep wells with almost vertical walls, line techniques were used to perform the measurements. In addition, an inventory of tectonic structures indicative of shearing stresses and relaxation of the rock massif in the passages of the cave was conducted. During the cave survey, small non-carbonate speleothems were also recorded.

\section{The characteristics of the Mroczna Cave}

The Mroczna Cave system developed along the main landslide scarp. The cave passages have a NW-SE elongation and form two levels. The upper part of the cave is composed of generally wider passages and large chambers formed among rock blocks. The bottom part is represented by a narrow crevice with tectonic microforms on the walls. Both levels are connected by a few wells among the rock blocks, the longest of which is $8 \mathrm{~m}$ long. Based on the orientation of the passages and their relation to the predominant directions of the cracks appearing in the main scarp of the landslide, several parts of the cave were distinguished as mentioned below (Fig. 3):

- crevice-type part composed of the two chambers near of the cave entrance,

- part oriented (elongated) similar to the predominant direction in the landslide scarp (composed of two levels - upper and lower),

- part transversal to the predominant direction in the landslide scarp,

- talus-type part of the cave (near its bottom).

Four parts in the cave were marked in different grey colors. A, B, and C - cross-sections of the cave passages. Numbers " 1 "-" 5 " indicate places of measurements in the cave, while the letters "a" and "b" indicate location of the walls in the upper sides and lower sides of cave passages (chambers).

The first part of the Mroczna Cave (I part - see above) is located directly next to the cave entrance and is composed of two chambers - wide passages in a NW-SE elongation. The blocks forming the walls of these chambers are strongly tilted in the direction concordant to the slope dip. Such an orientation of blocks results in the cross-sections through these chambers (A and B cross-sections on Fig. 3) being triangular in shape. The first cave chamber is $7 \mathrm{~m}$ long, $3-5 \mathrm{~m}$ wide, and $3 \mathrm{~m}$ high. The upper side wall is tilted at about $55^{\circ}$ (inclination change from vertical position) in the course of the slope dip, while the opposite chamber wall is tilted at around $30^{\circ}$ in the same direction (cross-section A in Fig. 3). The second cave chamber is about $4 \mathrm{~m}$ long, $3 \mathrm{~m}$ wide, and $4 \mathrm{~m}$ high. Both the upper side and the lower side walls are tilted (from the vertical position) at about $15^{\circ}$ in the direction of the slope dip (cross-section B in Fig. 3). The relationship between the cave walls in these parts indicates the gravity driven movements of the rock blocks which form the lower sides of these passages.

The second part of the Mroczna Cave (II) is elongated parallel to the predominant direction in the landslide scarp (Fig. 3). This part is composed of two segments (upper and lower) formed within one crevice but separated by rock blocks and debris. Moreover, the upper and the lower segments of this crevice differ in width and degree of structural disintegration. Therefore the measurements (reported below) were performed separately in both passages. The vertical distance that separates these two parts is $8 \mathrm{~m}$, and it is also the height of the longitudinal crevice. 
The upper segment is $8 \mathrm{~m}$ long, $1.3 \mathrm{~m}$ wide, and $3 \mathrm{~m}$ high. It is developed along a vertical crack. In the upper side wall there is a ledge $48 \mathrm{~cm}$ wide, inclined at an angle of $40^{\circ}$. The location of the ledge corresponds with the characteristic curvature in the opposite wall (cross-section $\mathrm{C}$ in Fig. 3). The lower segment which is continued below rock debris is a narrow passage developed along the same vertical system of cracks as the passage mentioned earlier. This narrow passage is a crevice around $8 \mathrm{~m}$ long, $0.8-1.3 \mathrm{~m}$ wide (to the depth of $14.5 \mathrm{~m}$ from the cave entrance). Rock boulders are wedged in the bottom of this passage. The rock discontinuities, along which the upper and the lower levels of this passage were formed, usually have smooth surfaces and form vertical walls, locally slightly wavy (A and B in Fig. 4). The walls of these passages are covered with tectonic microforms (A in Fig. 4). As proved by other studies on the Carpathians, these microforms indicate the occurrence and directions of tectonic stresses (shear stresses) in the rock massifs, which preceded the gravity driven mass movement (Książkiewicz 1968, Zuchiewicz 1997a, 1997b; Mastella, Szynkaruk 1998, Szczęsny 2003). There are also a few places with speleothems (secondary mineral formations) of the dripstone shape which are non-carbonate (Urban et al. 2007).

The southeastern part of the Mroczna Cave (III) is transversal to the predominant direction in the landslide scarp. This passage is a wide crevice with vertical walls, bending in a few places, and ultimately ending within rock blocks and debris on both sides. It has a length of 10 $\mathrm{m}$ and height of $2 \mathrm{~m}$. Its NE-SW course is unusual for this

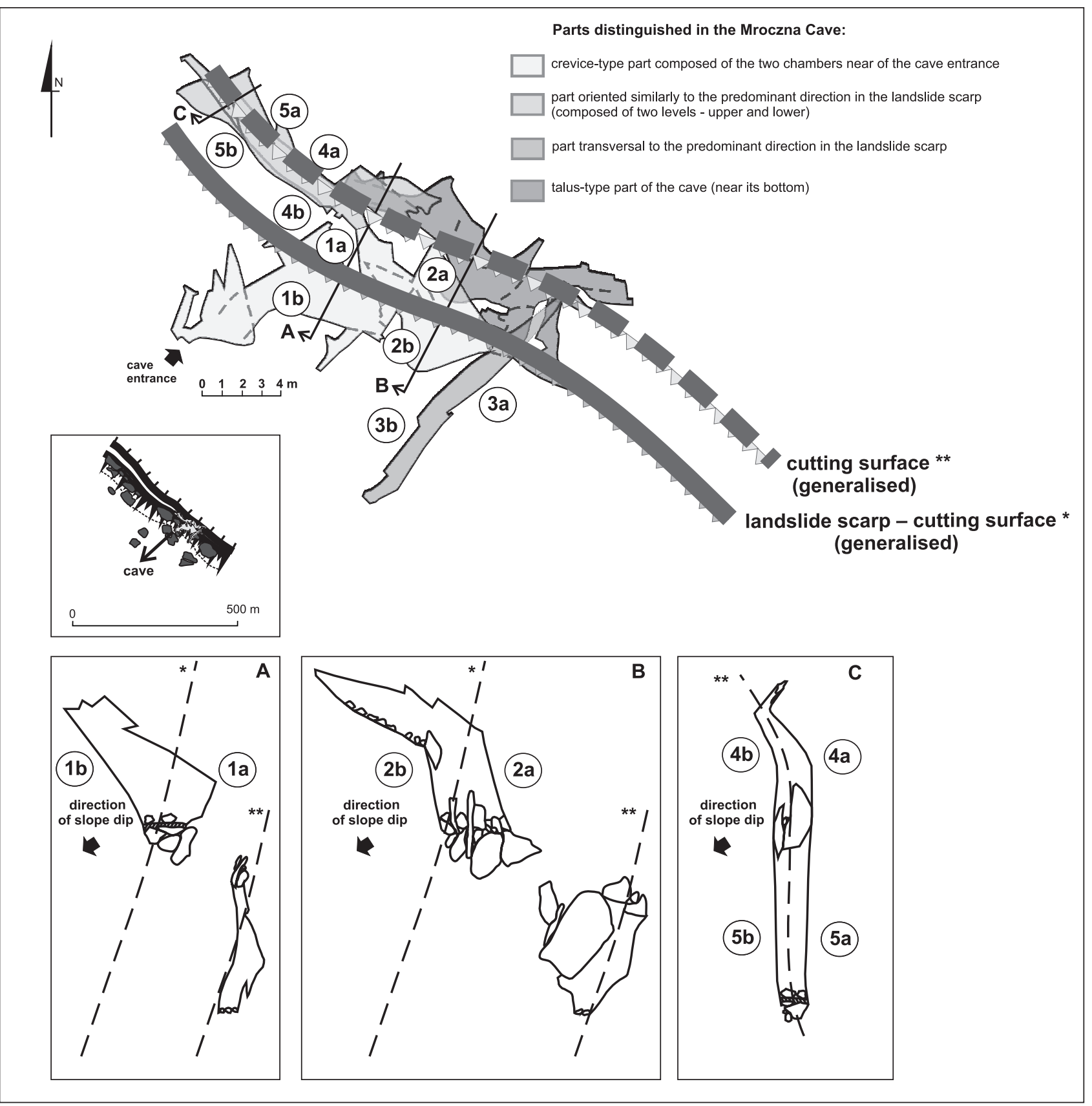

Fig. 3. The Mroczna Cave map with location of the main landslide scarp and cutting surface of the rock massif 


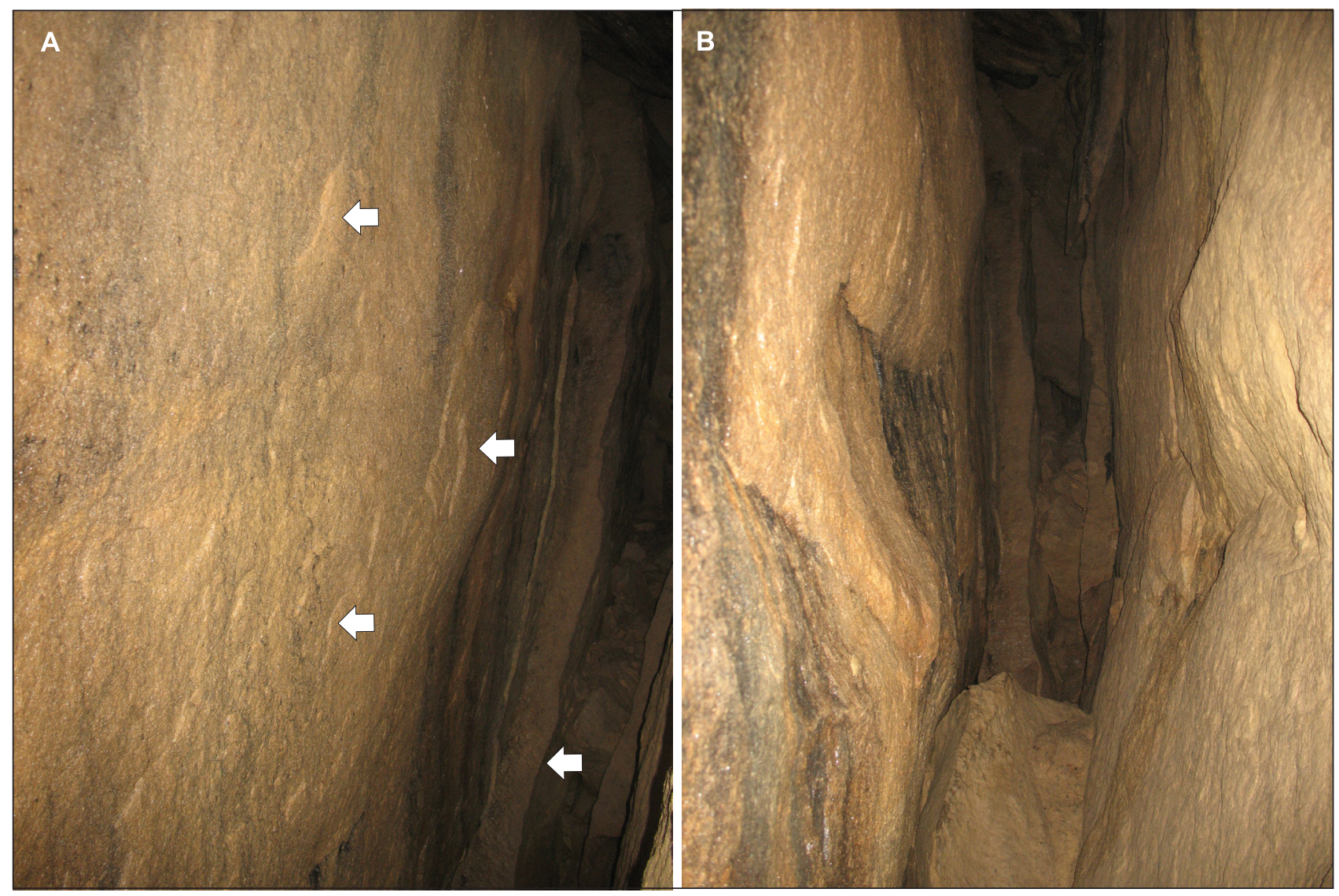

Fig. 4. Tectonic microstructures on the wall of a narrow passage (A); features related with phases indicate shear stress and relaxation of rock massif (B)

cave, associated with a system of cracks perpendicular to the main scarp (Fig. 3).

The last part (IV) which is located near the bottom of the cave (15.5 m below the cave entrance) resembles a talus-type of cave (Vitek 1983, Urban, Mochoń 1991). This is the part of the cave which is most disintegrated: it is composed of many cavities formed among large rock boulders of various orientation (rotated, wedged, etc.). The narrow passages in the NW direction are connected with the previously described $8 \mathrm{~m}$ high crevice (in part II), which is parallel to the main landslide scarp (Fig. 3).

\section{Tectonic determinants of the development of the Mroczna Cave}

The tectonic dissection of the rock massif resulted in the formation of a joint system that contributed to the subsequent development of gravity driven cutting and shearing surfaces. Consequently, within the mountain slopes the rock blocks were separated from the "intact" (in situ) parts of the rock massif, which resulted in gravitational mass movements in these parts of the slopes. In the case of Mt Kornuty, the main landslide scarp is also the outcrop of in situ sandstones (as per the definition of in situ forms by Alexandrowicz 1978). These sandstone strata generally dip to the $\mathrm{NE}\left(\mathrm{N} 25^{\circ}\right)$ at an angle of $32-60^{\circ}$, opposite to the direction of gravitational mass movements and slope dip. The main landslide scarp is linear and generally straight in a NW-SE direction. Toward the southeastern side its height decreases but there is a greater disintegration of the rock scarp, resulting in separated rock forms of sandstone. The contour and directional diagrams shown in Figure 5 represent measurements of a joint spatial orientation (as a summed data from several outcrops of the NW and SE part of the main scarp). The joint orientation in the landslide scarps of the northwestern and the southeastern parts are different, which makes it difficult to determine the in situ character of the main scarp; however, the joint system in the northwestern part of this scarp is very similar to the joint sets in the ridge outcrops. Cracks (rock faces) found commonly in the scarp are generally a set of vertical to steeply inclined $\left(50-90^{\circ}\right)$ longitudinal joints (N 110-120 ${ }^{\circ}$. The second joint set measured in the scarp represents the vertical transversal joints $\left(\mathrm{N} \mathrm{20} 0^{\circ}\right.$ ). These joint sets together form a conjugated system of orthogonal cracks (Fig. 5). Due to the differences in the orientation of the joint sets within the main landslide scarp, in situ spatial orientation is difficult to identify. The spatial orientation of the joint surfaces in the upper side walls of the cave passages will be considered as similar to the joint surfaces of the main landslide scarp.

Contour diagrams (equal-area plots, projection on lower hemisphere, number of measurements, and contour intervals are given below the diagram) and directional di- 


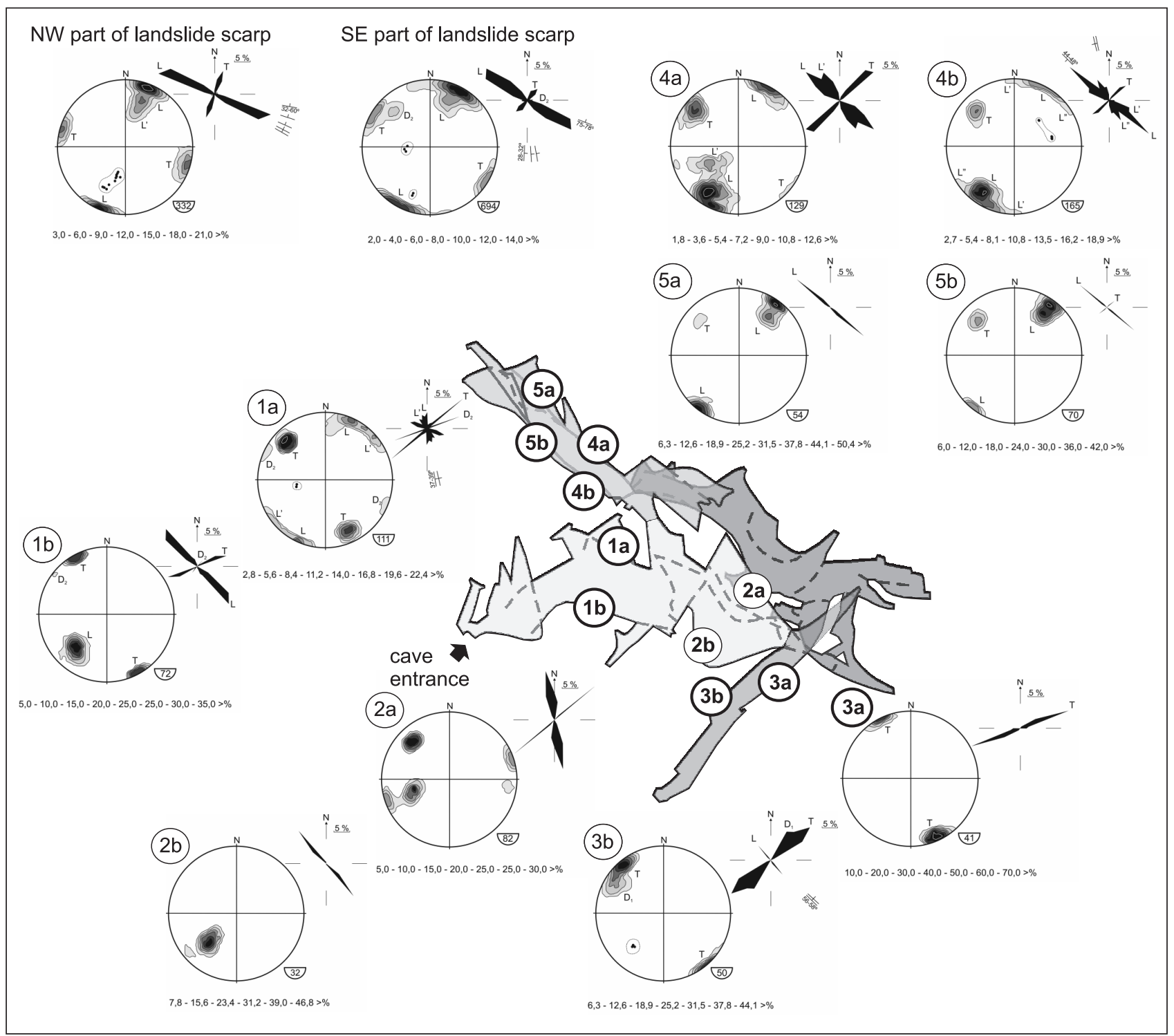

Fig. 5. Morphotectonic analysis of various parts of the Mroczna Cave

agrams of the joints in the upper and the lower side walls of the cave as well as those in the main scarp. Letters and numbers correspond to those given in Fig. 3.

In the part of the cave located next to the entrance (part I), the cave walls are strongly tilted in the direction of the slope dip (1 and 2 in Fig. 5). The dispersion of the joint directions of the upper side walls is the result of a structural disintegration of the rock massif. In this wall of the first chamber (1a in Fig. 5), the directions (azimuths) of the joints are represented by a longitudinal set (N 160$\left.180^{\circ}\right)$, a transversal set $\left(\mathrm{N} 230^{\circ}\right)$, and a diagonal set $(\mathrm{N}$ $250^{\circ}$ ). In the lower side wall of this chamber ( $1 \mathrm{~b}$ in Fig. $5)$, this dispersion is reduced and limited to the predom-

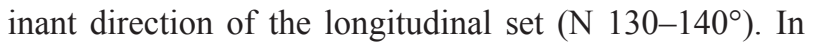
the second chamber ( $2 \mathrm{a}$ and $2 \mathrm{~b}$ in Fig. 5), the dispersion of joints is smaller. In its upper side wall, the directions (azimuths) of the joints are represented by a longitudinal

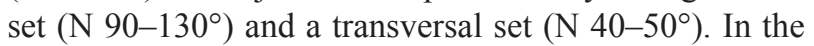
lower side wall of this chamber, the joint direction is reduced to one, a longitudinal set $\left(145^{\circ}\right)$, as a result of boul- ders tilted at an angle of $45^{\circ}$ (from the vertical position) (A and B in Fig. 6).

By comparing the spatial orientation of the joint sets of the upper and the lower side walls of the cave passages, one can determine the type of gravity driven mass movements that occurred in these passages. The difference in the orientation of the upper and the lower side walls in the next-to-the-entrance chamber (in part I) is distinctly illustrated by the different dips of the longitudinal sets in these sides: in the upper-side wall it is almost vertical, while in the lower-side wall it is around $60^{\circ}$, a difference of around $30^{\circ}$. It is also expressed by the difference in azimuth of the transversal set measured in these walls: in the upper-side wall - N 320 , while in the lower-side wall - N 335 , a difference of $15^{\circ}$, which indicates a counter-clockwise rotation around the vertical axis (1 and 2 in Fig. 5).

The cave part, which is oriented in the direction of the main landslide scarp (part II), is an extensive crevice $8 \mathrm{~m}$ high and $1.3 \mathrm{~m}$ wide and divided into two segments (passages) (Fig. 7). The ledge on the lower side wall and 


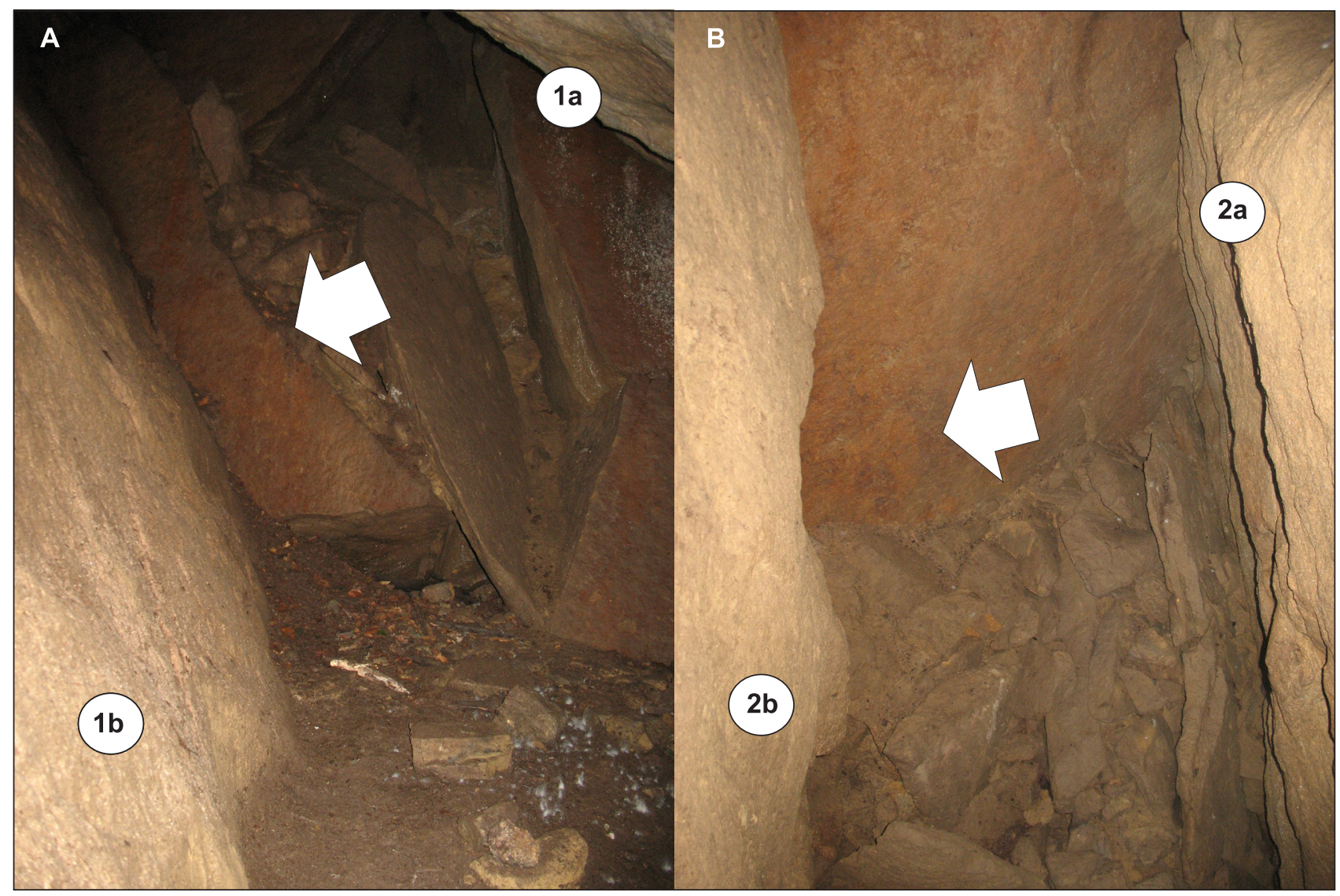

Fig. 6. The direction and type of gravitational movements (white arrows) of the rock massif framing the cave near its entrance (I) Letters and numbers correspond to those given in Fig. 3

the corresponding overhang on the opposite wall allow us to determine the translation at a distance of $75 \mathrm{~cm}(4 \mathrm{a}$ and $4 \mathrm{~b}$ in Fig. 7). In the walls of the upper segment ( $4 \mathrm{a}$ and $4 \mathrm{~b}$ in Fig. 5) the directions (azimuths) of the joints are represented by a diversified longitudinal set (azimuth from $\mathrm{N} 130^{\circ}$ up to $145-150^{\circ}$ and dip between $60^{\circ}$ and $90^{\circ}$ ) and a more unified transversal set (N 220-230 ). In the walls of the lower segment (5a and $5 \mathrm{~b}$ in Fig. 5) the directions (azimuths) of the joints are represented by a distinct longitudinal set $\left(\mathrm{N} 130^{\circ}\right)$ and a transversal set $\left(\mathrm{N} 230^{\circ}\right.$ ). Although the main type of movement of whole massif is here the toppling (suggested by comparison of $4 \mathrm{a}$ and $4 \mathrm{~b}$ diagrams with landslide scarp diagrams in Fig. 5 ), the reduced frequency of vertical joints of the longitudinal set in the lower side wall (5b in Fig. 5) indicates a slight tilting of the lower side block towards the NE (in relation to the upper side rock massif). It means that one of the type of movement in the parts oriented similar to the direction of the main landslide scarp is a slight backward rotation (i.e., opposite to the main direction of the landslide and slope dip). This type of movement can transform into a deep rotational slump of a structural nature during the progressive disintegration of the rock massif (Fig. 8).

The third (III) part of the cave comprises the passage which is transversal to the predominant direction in the landslide scarp ( 3 in Fig. 5). This passage is framed from both sides by boulders ex situ. The directions (azimuths) of the joints in this passage are represented by the differ- ence in the orientation of the transversal sets of the walls framing the passage, i.e., around $20^{\circ}$ (N 50-70 ${ }^{\circ}$ ) ( $3 \mathrm{a}$ and $3 \mathrm{~b}$ in Fig. 5). Assuming the conjugation between the movements of blocks framing the part of the cave near the entrance (I) and the third part of the cave (III), the north side wall of the third part can be called the "the lower side wall." Both the upper side as well as the lower side are rotated at an angle of $20-30^{\circ}$, as a result of a clockwise rotation around the vertical axis. Moreover, the slight difference in the dip of the joints of the transversal set in both walls of this passage indicates a small tilting of the lower-side block towards the NW.

In the deepest part of the Mroczna Cave (IV), significant movements of the rock blocks framing the cave passages have caused this part of the cave to resemble a talus-type cave (according to Vitek's 1983 classification). Such an apparent disintegration of the massif in this part of the cave makes a systematic interpretation of the movements impossible.

\section{Conclusions}

The location of the Mroczna Cave is directly in the zone of the main landslide scarp which is composed of several cutting surfaces. The cave is situated within the set of crevices that are directly connected to the rock scarp that developed due to the disintegration of this zone. The shape 


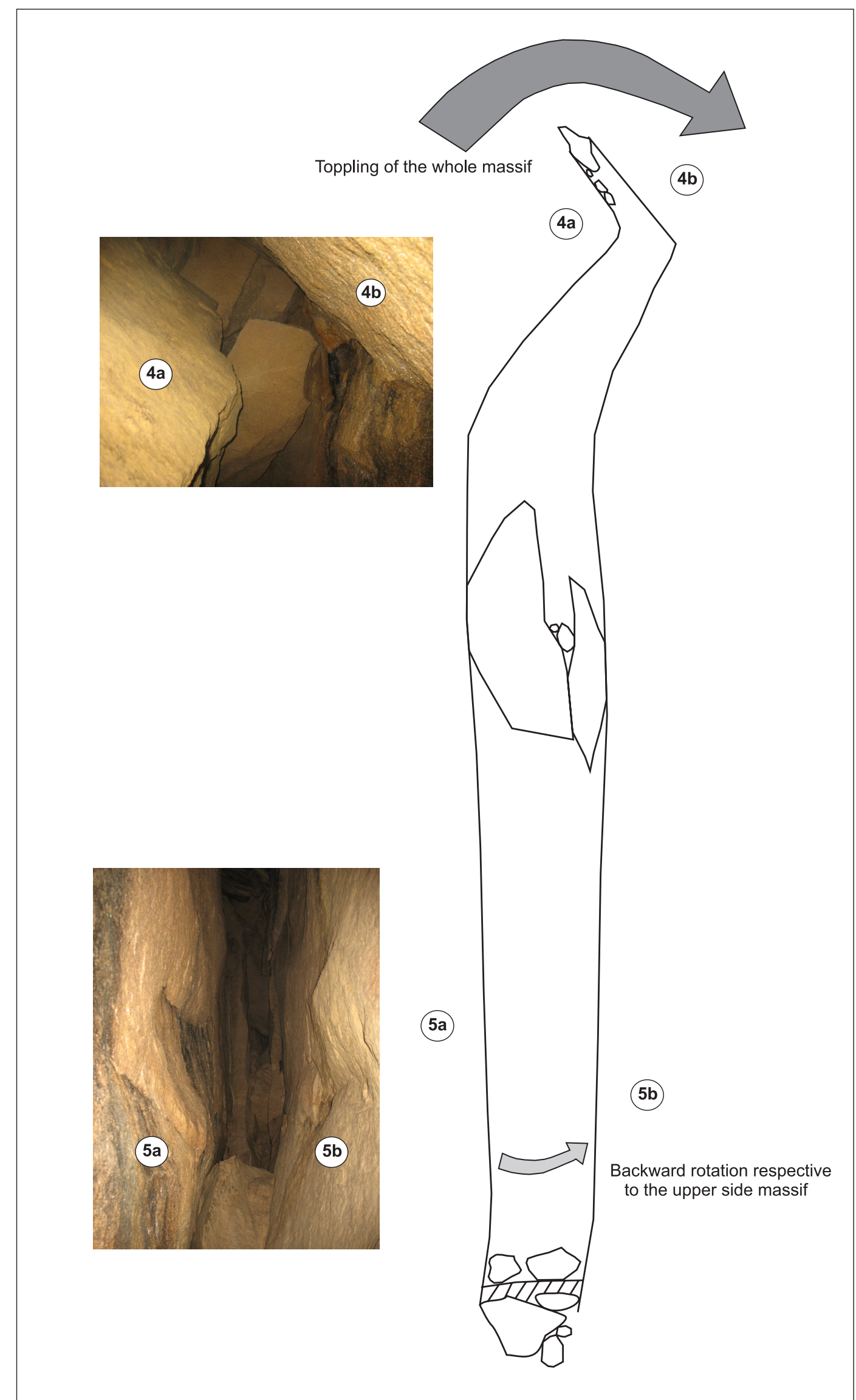

Fig. 7. The direction and type of gravitational mass movements (white arrows) within the part oriented similar to the predominant direction in the landslide scarp

Letters and numbers correspond to those given in Fig. 3 
1

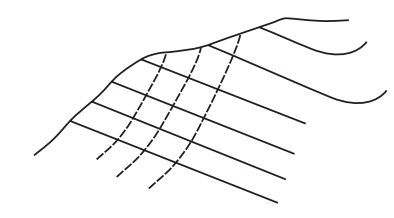

3

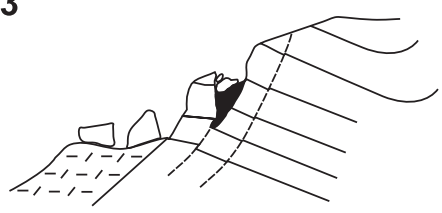

2

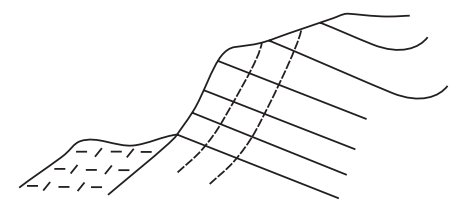

4

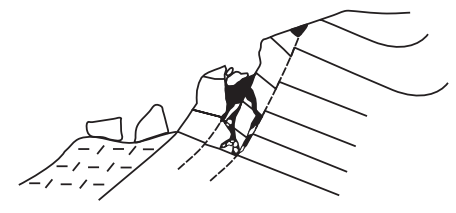

Fig. 8. Schematic model of the Mroczna Cave development

and direction of the cave passages indicate the dilatational nature of its development along a cutting surface that separates the downslope part of the massif from the main part of the mountain massif. The Mroczna Cave was formed during the secondary movements following the main phase of landslide formation, which led to the disintegration of the main scarp and the formation of the currently existing scarp. Its passages were formed (as widened, expanded joint crevices) during subsequent disturbances in the slope stability conditions (as has been determined for other landslides and caves connected with them in the Outer Carpathians, e.g. Janiga 1974, Puchejda 1989, Margielewski 1998, 2002, Margielewski, Urban 2003).

On the basis of the morphology of the cave passages, four parts were distinguished in the cave. The comparison of the spatial orientation of the upper and lower sides of the cave passages allows us to reconstruct several stages of cave development (Fig. 8) expressed in the different gravitational movements of rock blocks. Several types of movements were specified: toppling, backward rotation, and rotation around the vertical axis. The spatial situation of the part near the entrance of the cave (I) suggests that it is directly related to the movements along the current landslide scarp (Figs 3,6). The cave passages perpendicular to this scarp seem to be also genetically associated with the upper part of the cave. The main movements which led to the formation of these parts were toppling and rotation around the vertical axis. The next stage of cave development consisted of the formation of the passage of the second (II) part of the cave, which can be identified by the subsequent cutting surface (Figs 3, 7, 8). The strong disintegration of the massif observed in the deepest part (IV) of the cave suggests that the cutting surfaces observed within the cave and at the ground surface come together in the deep-seated part of the massif and contribute to the formation of the landslide shear zone.

Consequently, in accordance with Urban and Margielewski's (2013) morphogenetic classification, the parts close to the cave entrance and transverse to it (I and III) represent the intermediate type, whereas the part oriented similar to the predominant direction in the landslide scarp
(II) belongs to the initial type. According to the geomechanic criteria of this classification, most cave passages represent the dilational type, but the deepest part (probably associated with a shear zone) can be of the dilatancy type.

The passage walls are covered with tectonic microstructures that indicate the tectonic stresses predisposing the development of the joint sets. Therefore, these stresses are indirectly responsible for the direction of the structurally conditioned mass movements (Margielewski, Urban 2004, Margielewski 2006). In this case, the cave shape and contours are conditioned by them.

\section{Acknowledgments}

The author would like to thank Professor Włodzimierz Margielewski (Institute of Nature Conservation, Polish Academy of Sciences) for his valuable discussion. Thanks is also due to the reviewers for all their comments and suggestions which contributed to improving this paper significantly.

\section{References}

Alexandrowicz S.W., Alexandrowicz Z., 1988. Ridge-top trenches and rifts in the Polish Outer Carpathians. Annales Societatis Geologorum Poloniae 58: 207-228.

Alexandrowicz Z., 1978. Sandstone tors of the western Flysch Carpathians. Prace geologiczne Polskiej Akademii Nauk 113: 7-12, 50-76.

Bober L., 1984. Landslides in Polish Flysch Carpathians and their relation to geology of the region. Biuletyn Państwowego Instytutu Geologicznego 23(340): 115-153.

Flis J., 1958. Morphological forms affected by gravitational mass movements in the Beskid Sądecki Mountains. Rocznik Naukowo-Dydaktyczny Wyższej Szkoły Pedagogicznej 10(8): 35-53.

Gubała W. J., 2004. Zarys eksploracji jaskiniowej w okolicach Magury Wątkowskiej. Jaskinie Beskidzkie, Biuletyn Stowarzyszenia Speleoklub Beskidzki 5: 2-4.

Imrich P., Kováčik M., Bóna J., Majerničková F., 2007. Geological control of the gravitational processes in Spišská Hill pseudokarst region. Nature Conservation 63: 47-55.

Jakubowski K., 1974. Contemporary trends in the transformation of landslide forms in the Holocene development cycle of landslides in the flysh Carpathians. Prace Muzeum Ziemi 22: 169-193. 
Janiga S., 1974. Comment on the origin of caves in the Dukla region. Czasopismo Geograficzne 3(45): 355-360.

Kapturkiewicz A., 2006. Działalność inwentaryzacyjna Stowarzyszenia Speleoklub Baskidzki. Jaskinie Beskidzkie, Biuletyn Stowarzyszenia Speleoklub Beskidzki 6: 37-43.

Klassek G., Mikuszewski J. 1997. Tills: Przyrodnicza charakterystyka jaskiń, warunków ich występowania i rozwoju w obszarze polskich Karpat fliszowych. In: Jaskinie Polskich Karpat Fliszowych, Wydawnictwo Polskiego Towarzystwa Przyjaciół Nauk o Ziemi, Warszawa, vol. 1: 5-18.

Kopciowski R., Jankowski L., Zimnal Z. 1997. Szczegółowa Mapa Geologiczna Polski (Detailed Geological Map of Poland) 1:50 000, arkusz Osiek (manuskrypt). Centralne Archiwum Państwowego Instytutu Geologicznego Państwowego Instytutu Badawczego, Warszawa.

Książkiewicz M., 1968. Observations on jointing in the Flysch Carpathians. Rocznik Polskiego Towarzystwa Geologicznego 2-3(38): 335-379

Lach J., 1970. Rock measures in the Magurian of Watków and their phases of development. Rocznik Naukowo-Dydaktyczny Wyższej Szkoły Pedagogicznej, 5(40): 27-33.

Margielewski W., 1992. Landslide forms of the Jaworzyna Krynicka ridge in Popradzki Park Krajobrazowy (Landscape Park of Poprad). Chrońmy Przyrodę Ojczystą 5(48): 5-16.

Margielewski W., 1997. Protection of landslide relief elements of Mount Mogielica (Beskid Wyspowy Mts). Chrońmy Przyrodę Ojczystą 4(53): 85-94

Margielewski W., 1998. Development of the landslide forms in Barnowiec (Beskid Sądecki Mts, Outer Carpathians) in the light of the analysis of structural background of the landslides in the Flysch Carpathians. Przegląd Geologiczny 5(46): 436-448.

Margielewski W., 1999. Landslide forms of the Gorce National Park and their role in shaping the geo- and biodiversity of this mountain range. Chrońmy Przyrodę Ojczystą 5(55): 23-48.

Margielewski W., 2002. Geological control on the rocky landslides in the Polish Flysch Carpathians. Folia Quaternaria 73: 53-68.

Margielewski W., 2006. Structural control and types of movements of rock mass in anisotropic rocks: case studies in the Polish Flysch Carpathians. Geomorphology 77: 47-68.

Margielewski W., 2009. Patterns of gravitational movements of rock masses in landslide forms of the Polish Flysch Carpathians. Przegląd Geologiczny 10(57): 905-917.

Margielewski W., Urban J., 2003. Crevice-type caves as initial forms of rock landslide development in the Flysch Carpathians. Geomorphology 54, 3-4: 325-338.

Margielewski W., Urban J., 2004. Crevice-type cave Diabla Dziura in Bukowiec (Rożnów Foothill, Outer Carpathians) as an initial stage of deep-seated land-slides development in the Flysch Carpathians (S Poland). Przegląd Geologiczny 12(52): 1171-1178.

Margielewski W., Urban J., Szura Cz., 2007. Jaskinia Miecharska cave case study of a crevice-type cave developed on a sliding surface. Nature Conservation 63: 57-68.

Mastella L., Szynkaruk E., 1998. Analysis of the fault pattern in selected areas of the Polish Outer Carpathians. Geological Quarterly 3(42): 263-276.
Mastella L., Zuchiewicz W., Tokarski A, Rubinkiewicz J., Leonowicz P., Szczęsny R., 1997. Application of joint analysis for palaeostress reconstructions in structurally complicated settings, case study from Silesian Nappe, Outer Carpathians, Poland. Przegląd Geologiczny 10/2(45): 1064-1066.

Mochoń A., Urban J., 1989. Pseudokras - pseudoproblem? Przegląd Geologiczny 3: 167-168.

Puchejda W., 1989. The origin of the Trzy Kopce cave in the Silesian Beskidy Mts. Kras i Speleologia 6: 66-76.

Pulina M. (ed.), 1998. Jaskinie Polskich Karpat Fliszowych. Wydawnictwo Polskiego Towarzystwa Przyjaciół Nauk o Ziemi, Warszawa, vol. 3: 31-43.

Rączkowski W., Wójcik A., Zimnal Z., Nescieruk P., Paul Z., Ryłko W., Szymakowska F., Żytko K., 1995. Mapa Geologiczna Polski (Polish Geological Map) 1:200 000, arkusz Jasło, wersja A-Mapa utworów powierzchniowych. Państwowy Instytut Geologiczny.

Szczęsny R., 2003. Reconstruction of stress directions in the Magura and Silesian Nappes (Polish Outer Carpathians) based on analysis of regional folds. Geological Quarterly 47: 289-298.

Ślączka A. (ed.), 1977. Przewodnik do XLIX Zjazdu Polskiego Towarzystwa Geologicznego. Wydawnictwo Geologiczne, Warszawa: 9-25, 73-75.

Świdziński H., 1933. Diabli Kamień - skałka piaskowca magurskiego koło Folusza („La Pierre du diable”, Grés de Magura, près de Folusz, district de Jasło, Karpates). Zabytki Przyrody Nieożywionej 2: 129-131.

Świdziński H., 1936. Budowa geologiczna Kornutów (Geological structure of Kornuty). In: T. Sulma (ed.), Kornuty - rezerwat na Łemkowszczyźnie (Kornuty bei Gorlice als Naturschutzgebiet). Ochrona Przyrody 16: 57-58.

Tokarski A., 1946. Zachodnia część fałdu Mrukowej oraz możliwości ropne terenu Pielgrzymki i Folusza. Nafta 2 (10-12): 378-385, 416-422.

Urban J., 2014. „Pseudokarst” during the $16^{\text {th }}$ International Congress

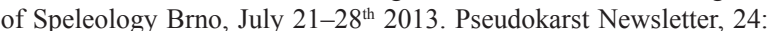
34-38.

Urban J., Margielewski W., 2013. Types of non-karst caves in Polish Outer Carpathians - historical review and perspectives. 16th International Congress of Speleology, Brno, 21-28 July 2013, 3: 314-319.

Urban J., Margielewski W., Žák K., Schejbal-Chwastek M., Mleczek T., Szura Cz., Hercman H., Sujka G., 2007. The calcareous speleothems in the pseudokarst Jaskinia Słowiańska - Drwali cave. Nature Conservation 63: 119-128.

Urban J., Mochoń A., 1991. Pseudokras definicja, rodzaje form i ich występowanie. Kwartalnik geologiczny 4(34): 776-777.

Viték J., 1983. Classification of Pseudokarst forms in Czechoslovakia. International Journal of Speleology 13: 1-18.

Zuchiewicz W., 1997a. Reorientation of the stress field in the Polish Outer Carpathians in the light of joint pattern analysis. Przegląd Geologiczny 1(45): 105-109.

Zuchiewicz W., 1997b. Distribution of jointing within Magura Nappe, West Carpathians, Poland, in the light of statistical analysis. Przeglad Geologiczny 6(45): 634-638.

Żytko K. (ed.), 1973. Przewodnik geologiczny po Karpatach fliszowych. Wydawnictwo Geologiczne, Warszawa: 55-59, 62-72, 102-110. 